DOI: http://dx.doi.org/10.37253/jad.v2i2.4285

\title{
Analisis Rumah Panggung yang ada di Pasar Lama, Meral Kota, Karimun
}

\author{
${ }^{1}$ Yessy Christanti Silaban, ${ }^{2}$ Yoseph Seno Prakoso, ${ }^{3}$ Antony, ${ }^{4}$ Friendy, \\ 1,2,3 Universitas Internasional Batam, Batam \\ iienrong21@gmail.com
}

\author{
Informasi Naskah \\ Diterima: 16/12/2020; Disetujui terbit: 16/12/2021; Diterbitkan: 31/12/2021; \\ http://journal.uib.ac.id/index.php/jad
}

\begin{abstract}
ABSTRAK
Permukiman pesisir merupakan salah satu jenis kawasan unik yang membutuhkan pendekatan khusus dalam memahami karakteristiknya. Selama ini permukiman pesisir di Indonesia umumnya dikenal memiliki perkembangan yang sangat cepat dan dinamis dimana salah satu penyebabnya adalah tingginya tingkat migrasi pendatang, termasuk di wilayah studi kasus Meral Kota. Konsep pengembangan permukiman seringkali tidak sukses dalam implementasinya karena kurangnya pemahaman mengenai karakteristik pola perkembangan permukiman sehingga diperlukan pendekatan khusus dalam studinya. Meral Kota merupakan salah satu kawasan permukiman pesisir yang ditetapkan sebagai kawasan minapolitan di Kab.Karimun dan seperti permukiman pesisir pada umumnya, wilayah ini memiliki peran vital dalam kegiatan ekonomi karena integrasi fungsi permukiman dan ekonomi merupakan budaya dan karakteristik eksisting. Artikel ini bertujuan untuk mengalisis Rumah Panggung yang ada di Pasar Lama, Meral Kota, Karimun. Diskusi dititikberatkan pada pendekatan Metode Kualitatif berserta gabungan dengan beberapa metode lainnya.
\end{abstract}

Keyword: Rumah Panggung, Pasar Lama, Ekonomi, Kualitatif, Permukiman

\section{ABSTRACT}

Coastal settlements are one type of unique area that requires a special approach in understanding its characteristics. So far, coastal settlements in Indonesia are generally known to have very fast and dynamic developments, one of which is the high rate of migrant migration, including in the case study area of Meral Kota. The concept of settlement development is often unsuccessful in its implementation due to a lack of understanding of the characteristics of settlement development patterns so that a special approach is needed in its study. Meral Kota is one of the coastal settlement areas designated as a minapolitan area in Karimun Regency and like coastal settlements in general, this area has a vital role in economic activities because the integration of settlement and economic functions is an existing culture and characteristic. This article aims to analyze the Stage House in the Old Market, Meral City, Karimun. The discussion focused on the Qualitative Method approach and its combination with several other methods.

Keyword: Stilt-house, Old Market, Economy, Qualitative, Settlement

\section{PENDAHULUAN}

\section{Latar Belakang}

Meral Kota merupakan salah satu kelurahan yang ada di kecamatan Meral, Kabupaten Karimun, Provinsi Kepulauan Riau, Indonesia, dan Sekaligus menjadi pusat pemerintah kecamatan Meral. Kelurahan ini memiliki jumlah penduduk 7.424 jiwa, dengan luas wilayah 8,20 $\mathrm{km}^{2}$ dan di bagi menjadi $26 \mathrm{RT}$ dan $6 \mathrm{RW}$. Meral kota memiliki batas wilayah, mulai bagian utara Kelurahan Harjosari, bagian Timur terdiri dari Baran Barat dan Baran Timur, dan bagian Barat terdiri dari Kelurahan Sei Raya.

Kawasan Permukiman Pesisir adalah permukiman yang terdiri dari Tempat tinggal atau hunian sebagai kawasan permukiman beserta sarana dan prasarananya, Kawasan tempat 
bekerja, dalam hal ini berupa area alamiah tempat nelayan bekerja yakni lautan dan saranasarana buatan tempat melakukan kegiatan ekonomi lainnya yang menunjang atau berkaitan dengan kegiatan ekonomi. Karakteristik umum Permukiman Kawasan Pesisir adalah secara Gemografi kawasan pesisir yang memiliki ciri-ciri pada umumnya adalah Imigran dengan pertumbuhan jumlah penduduk yang sangat cepat, menempati lahan ilegal, dan seringkali kurang memperhatikan kualitas lingkungan. Lokasi dimana kawasan Permukiman Pesisir berada rentan terhadap konflik kepentingan berbagai pihak. Lahan pesisir, tepian sungai, muara sungai, dan daerah antara daratan dan perairan. Kebijakan berbagai instansi yang berbeda, dimana satu sama lain harus diintegrasikan dan saling melengkapi.

Meral Kota merupakan salah satu kawasan permukiman pesisir yang ditetapkan sebagai kawasan minapolitan, di Kab.Karimun dan seperti permukiman pesisir pada umumnya, wilayah ini memiliki peran vital dalam kegiatan ekonomi. Oleh karena itu perkembangan di kawasan ini tidak merata dari dulu hingga sekarang, contohnya dulu kawasan ini hanya di bangun rumah panggung dengan material kayu yang tidak merata sehingga mudah perampokan masuk ke dalam rumah yang di sasarannya, dan rumah panggung juga mudah terbakar.

Di Meral kota masih ada beberapa tempat yang masih menggunakan rumah panggung kayu seperti di tempat pasar lama, juga ada beberapa bagian belakang rumah dan gudang menggunakan material kayu karenakan lebih efesien untuk sandar kapal nelayan.

Bagian kawasan perumahan atau kawasan daratan tinggi, pada umunnya daerah jalan utama akan di bangun ruko sedangkan bagian dalam gang gang kecil atau jalan kecil akan di bangun rumah tinggal bisa saja. Ada beberapa tempat juga masih menggunkan rumah panggung darat misalnya di bagian kawasan gang awang nur. Perumahan yang ada di Meral Kota bisa di katakan berkembang sangat cepat dan signifikat, Meral Kota sekarang sudah memiliki perumahan sekitar 3 - 4 daerah seperti dekat sekolah Bina Bangsa ( Permata Asri ), Perumahan Wonosari Asri, Perumahan Green Permata dan lain -lain.

Perbandingan rumah panggung darat dan rumah panggung yang berada pesisir laut adalah desain dan arsitekturnya di karenakan kedua rumah tersebut memiliki fungsi yang sama tetapi letak geografi.

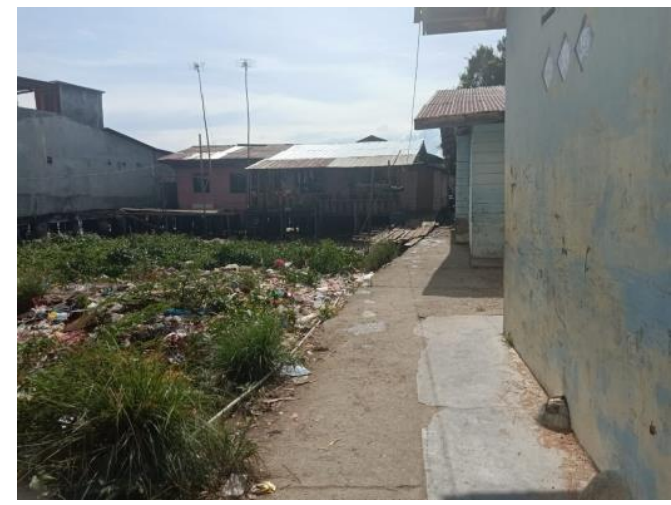

Rumah Panggung Pesisir pantai yang berada di Meral Kota

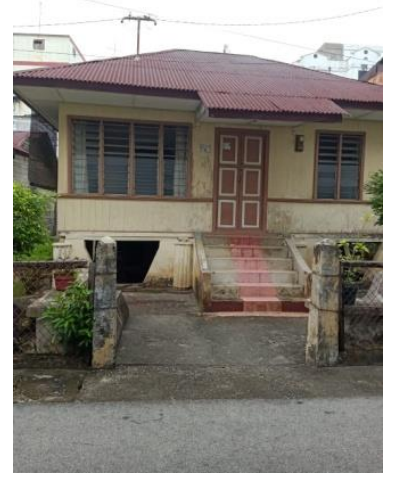

Rumah Panggung darat yang berada di Meral Kota 


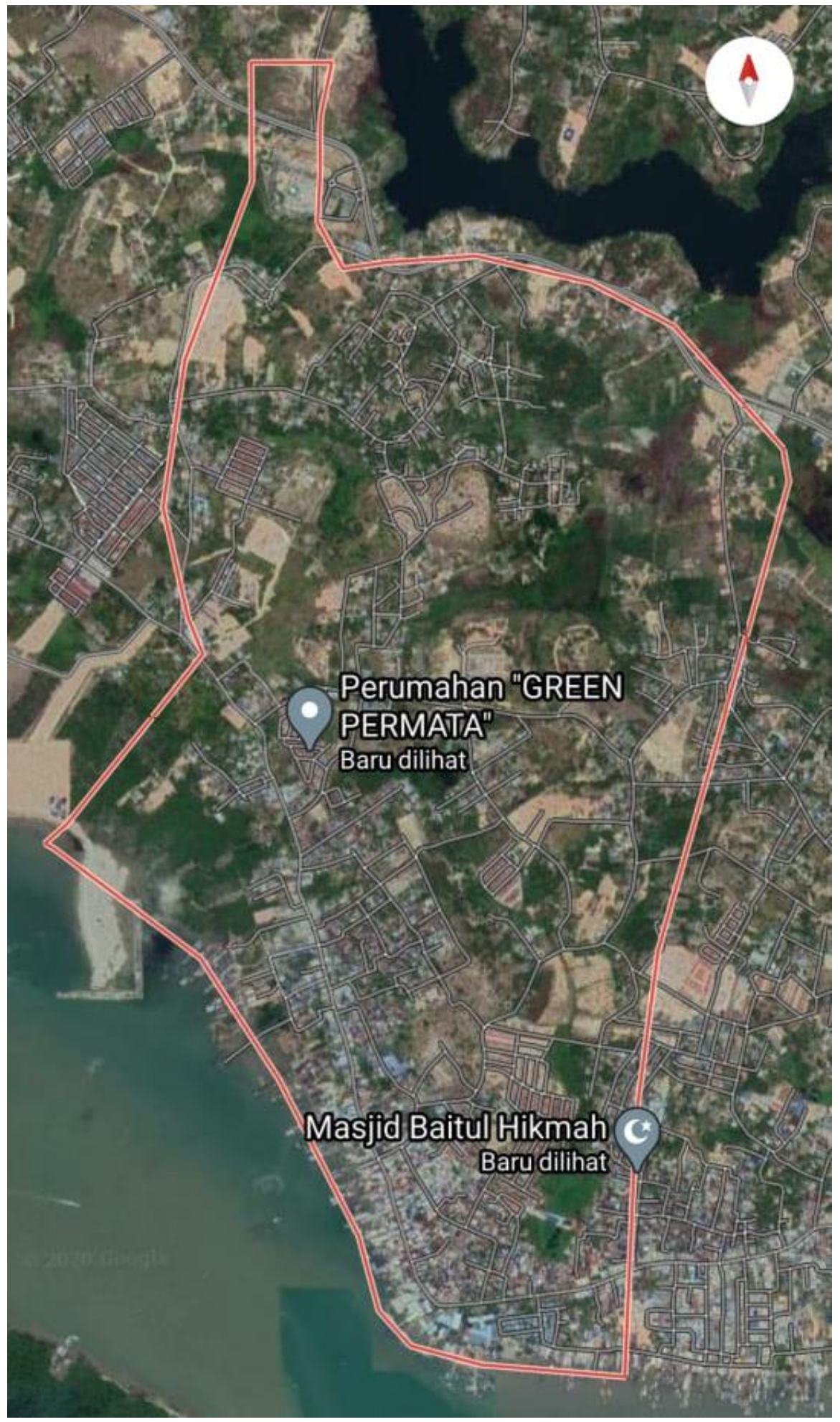


1.1 Rumusan Masalah

Berdasarkan latar belakang yang telah diuraikan di atas, dapat dirumuskan beberapa permasalahan yaitu:

1. Rumah panggung yang ada di kawasan pesisir tidak terlalu koko dan murah rapuh karena Air laut dan angin laut.

2. Apakah pembangunan rumah panggung sudah sesuai kriterialnya? (Tempat pasar lama).

1.2 Tujuan Penelitian

Dari perumusan masalah yang telah diuraikan sebelumnya maka tujuan dari penelitian ini adalah untuk:

1. Cara menanggapi masalah rumah panggung yang ada di tempat pasar lama.

2. Apakah ada solusi untuk rumah panggung yang berada di tempat pasar lama.

1.3 Batasan Masalah

Batasan-batasan masalah pada penelitian ini adalah sebagai berikut:

1. minimnya infomasi terkait daerah sekitar pasar lama

2. Di karenakan keadaan Covid 19 maka penelitian menggunakan metode kualitatif

\section{Kajian Pustaka}

\subsection{Penataan Ruang Permukiman}

Rumah panggung yang berada di tempat pasar lama itu tidak bergitu baik kondisinya hanya beberapa saja yang kondisinya masih bisa di bilang layak di tinggal. Kedua, di karenakan kondisi setempatnya kurang di perhatikan oleh pemerintah maka tempat tersebut jadi kotor dan pesisir pantai jadi rusak. Ketiga, dalam kriterial rumah panggung yang berada di tempat pasar lama tersebut tidak bergitu bagus di karenakan rumah di sana saling berdempetan kadang mau masuk ke suatu rumah tertentu harus melewati gang atau rumah orang lain.

\subsection{Kebersihan Lingkungan}

Kebersihan lingkungan merupakan keadaan bebas dari kotoran, termasuk di dalamnya, debu, sampah, dan bau. Kebersihan lingkungan merupakan salah satu faktor pengaruh lingkungan terhadap masyarakat dengan kehidupan sehat. Kebersihan lingkungan pada pasar bisa di nilai sangat buruk di karenkan kepadatan penduduk di sana sehingga seling terjadi buang sampah sembarangan dan menurut mereka buang sampah ke laut jauh lebih efesien tetapi mereka tidak tau penyebab kerusakan lingkungan sekitarnya.

\section{Metode Penelitian}

Penelitian kami dengan menggunakan cara kuantitatif. Sumber data yang kami terima adalah data sekunder di karenakan rumah panggung yang berada di pasar lama itu saling berdempetan dan ada juga yang harus melewati rumah lain sehingga susah di tentukan berapa jumlah rumah panggung yang berada di sana. Kami juga meneliti dari peta google map.

Dari hasil survey kami, kami menemukan bawah hasil dari google map sama survey ke lokasnya secara langsung itu tidak sama. Mungkin hasil dari google map tersebut belum update dalam lokasi tersebut. Inilah hasil dari perbedaan dari google map sama survey ke lokasinya secara langsung ( dari kedua hasil penelitian kami itu hanya secara sekunder di karenakan ada beberapa kendala dalam penelitian kami ). 


\begin{tabular}{|c|c|c|}
\hline Hasil dari & $\begin{array}{c}\text { Rumah Panggung yang } \\
\text { layak di tinggal }\end{array}$ & $\begin{array}{c}\text { Rumah Panggung yang } \\
\text { tidak layak di tinggal }\end{array}$ \\
\hline Google Maps & Kisaran \pm 20 Rumah & $5-6$ Rumah \\
\hline Survey ke lokasi & Kisaran $20-25$ & $5-8$ Rumah \\
\hline
\end{tabular}

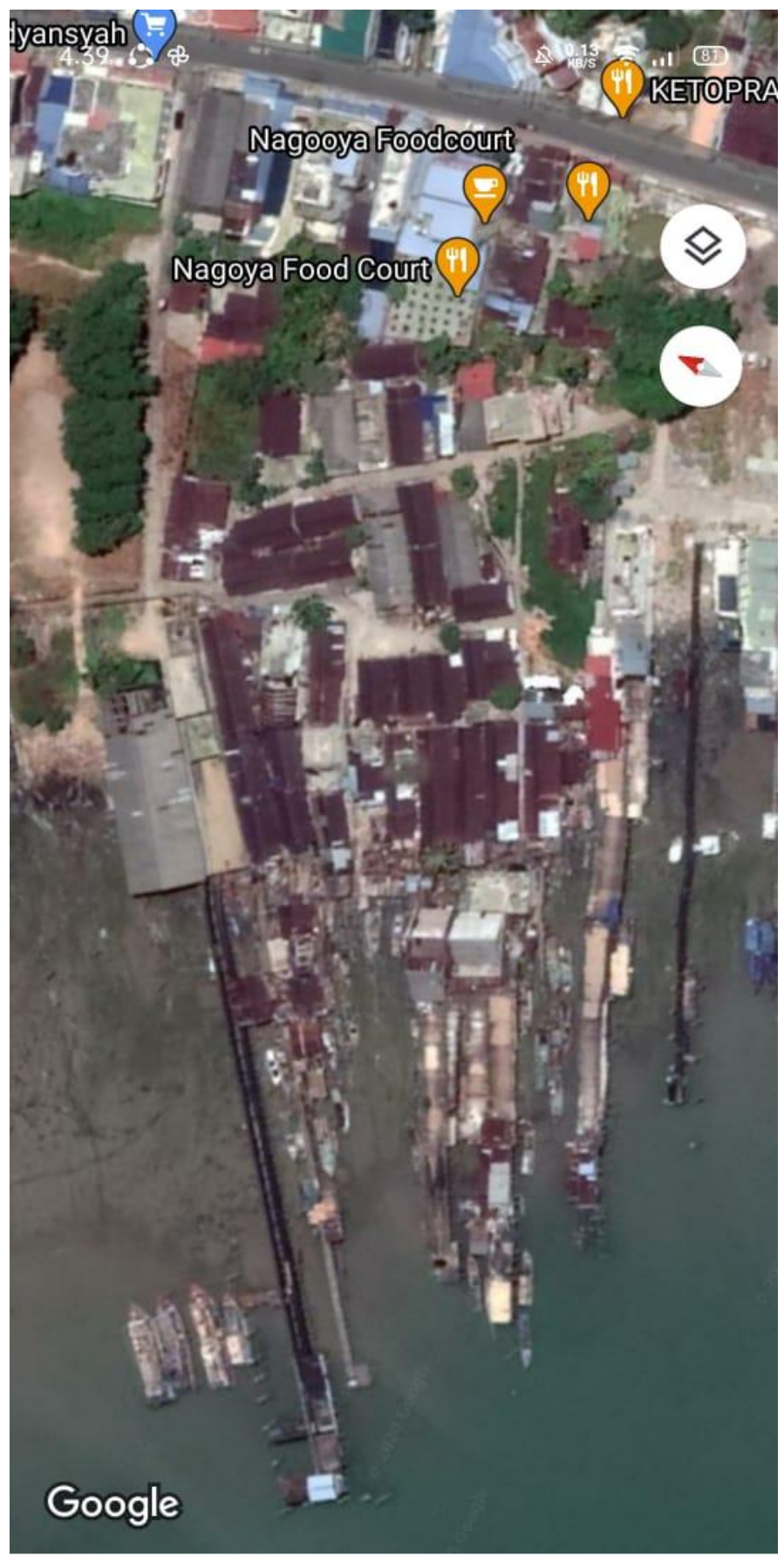




\section{Hasil dan Pembahasan}

Pasar lama merupakan salah satu permukiman nelayan perkotaan yang timbul karena proses urbanisasi, terlihat dari dominasi penghuni permukiman yang berasal dari Melayu dan suku heterogen, dengan aktivitas dan pola arsitektur rumah panggung nelayan yang masih cukup kental dengan adat dan budaya mereka.

Pasar lama awalnya adalah pasar yang cukup besar pada masa. Pada saat itu nelayan membawa tangkapan ikan mereka menjualnya di pasar tersebut sehingga mereka pun mulai membuat jembatan untuk sandar kapal sehingga lebih efektif dan efisien. kemudian mulailah beberapa punduduk membangun rumah panggung nelayan disana dan lama kelamaan kepadatan penduduk disana mulai banyak dan rata-rata kepemilikan tanah bukan milik penduduk permukiman namun milik pihak lain yang tidak bermukim di dalam Kawasan. Namun seiring waktu para pemilik tanah mulai sadar dan memperhatikan tanahnya sebagai asset mereka, sehingga saat ini rumah - rumah nelayan yang awalnya berdiri diatas tanah bukan miliknya harus membayar sewa terhadap pemilik tanah.

Karena area terbuka di dalam Kawasan menyebabkan masyarakat banyak beraktifitas di jalan lingkungan (gang), pos keamanan lingkungan, teras rumah, bahkan di kolong rumah panggung. Hal ini menyebabkan sosialisasi antar penduduk permukiman terjalin dengan baik. Selain itu, mereka juga memarkirkan kendaraan mereka di jalan lingkungan atau kolong rumah panggung karena keterbatasan lahan. Lahan untuk bercocok tanam juga sulit didapatkan, sehingga media pot menjadi pilihan mudah untuk bisa membuat rumah lebih hijau.

Di Pasar lama, rumah panggung dengan arsitektur tradisional Melayu dan suku heterogen terlihat sangat mendominasi permukiman, dikarenakan mayoritas penduduk kampung ini adalah masyarakat tradisional Melayu dan suku heterogen yang merantau dan akhirnya bermukim. Berdasarkan hasil pengamatan di lapangan, ditemukan bahwa 90\% - 95\% bangunan di dalam permukiman pasar lama berbentuk panggung.

Tipe bangunan di dalam lokasi studi adalah bangunan kopel, yaitu bangunan yang rapat dengan salah satu sisinya atau tidak terdapat jarak antar bangunan, dengan Pola Radial dalam Kawasan. Pola Radial, pola jalan yang dipakai apabila kondisi topografi berkontur. Pola di sana di sebabkan karena luas lahan masing-masing pemilik tidak sama.

Ada beberapa jenis bangunan di dalam lokasi studi; bangunan permanen berdinding batu bata ringan (hebel), bangunan semi permanen dengan dinding tembok atau multiplek, dan bangunan non permanen berbahan kayu yang mendominasi lokasi studi, dengan atap dari genteng/seng/asbes dan lantai dari keramik/kayu/triplek. Rata-rata berupa bangunan rumah panggung 1 lantai.

Di lokasi studi, rumah penduduk didominasi dengan bangunan berbahan kayu dan beberapa rumah sudah merupakan bangunan permanen berbahan batako dan bata merah. Namun hampir semua rumah menggunakan atap seng karena harga yang terjangkau.

\section{Kesimpulan}

Bawah rumah panggung yang ada di Pasar Lama, Meral, Karimun diperngaruh oleh rumah panggung nelayan dikarenakan rumah panggung nelayan sangat gampang di bangun dan hampir tidak ada ornamen, tidak seperti rumah panggung di darat ada begitu banyak ornamen dikarenakan di pengaruhi oleh adat Melayu.

Rata-rata kepemilikan tanah bukan milik penduduk permukiman namun milik pihak lain yang tidak bermukim di dalam Kawasan dan saat membangun rumah panggung mereka tidak memiliki Izin Mendirikan Bangunan (IMB) sehingga pembanguna disana menjadi berantakan. 


\section{Daftar Pustaka}

Sato, Koji. 1991. Menghuni Lumbung : beberapa pertimbangan mengenai asal usul konstruksi rumah panggung di kepulauan pasifik. Jurnal Antropolgi Indonesia No.49. https://doi/org/10.7454/ai.v0i49.3291

Wiadnya, Dewa Gede Raka. 2011. Konsep Perencanaan Minapolitan Dalam Pengembangan Wilayah. Fakultas Perikanan \& IImu Kelautan (FPIK), Universitas Brawijaya. 